\section{Mainstreaming climate adaptation and mitigation policy: Towards multi-level climate governance in Melaka, Malaysia}

By: Zen, IS (Zen, Irina Safitri) ${ }^{[1]}$; Al-Amin, A (Al-Amin, Abul Quasem) ${ }^{[2,3,4,5]}$; Doberstein, B (Doberstein, Brent) ${ }^{[4]}$

View Web of Science ResearcherID and ORCID

\section{URBAN CLIMATE}

Volume: 30

Article Number: UNSP 100501

DOI: $10.1016 / j . u c l i m .2019 .100501$

Published: DEC 2019

Document Type: Article

\section{Abstract}

Cities' responses to the challenge of climate change mainly relate to urban spatial planning and capacity-building initiatives. Those are enhanced by supportive climate adaptation policies at the sub-national level, which open up potential benefits and opportunities. Using the city of Melaka as a case study, this paper examines the importance of supportive climate adaptation policies using 'good practices' within a multi-level climate governance framework. This framework is evaluated by horizontal and vertical dimensions which assess policy actions designed to close the gap between national and local levels. Melaka is aiming to become a greener city, and its carbon reduction target is intended to support climate mitigation. This is discussed in relation to dynamic horizontal and vertical interactions at various scales. This study also examined why Melaka is considered a testing ground for climate mitigation projects that may subsequently be applied in other Malaysian states. A dual, collaborative, top-down and bottom-up approach and likely ways forward are also discussed as elements of good multi-level governance. The findings of this study should inform the application of multi-level governance in other states in Malaysia and elsewhere with similar ecological and economic contexts.

\section{Keywords}

Author Keywords: Climate change; Adaptation; Mitigation; Multi-level climate governance; Green City; Malaysia

KeyWords Plus: NEW-YORK-CITY; CO2 EMISSIONS; ADAPTIVE CAPACITY; CARBON EMISSIONS; URBANIZATION; IMPACT; GROWTH; CITIES; CHINESE; PLANYC

Author Information

Reprint Address: Al-Amin, A (reprint author)

Univ Tenaga NasI UNITEN, Inst Energy Policy \& Res IEPRe, Kajang, Malaysia. Addresses:

+ [1] Int Islamic Univ Malaysia, Dept Urban \& Reg Planning, Kulliyyah Architecture \& Environm Design, Jalan Gombak 51000, Kuala Lumpur, Malaysia

[ 2 ] Univ Tenaga NasI UNITEN, Inst Energy Policy \& Res IEPRe, Kajang, Malaysia

+ [3] MIT, Dept Urban Studies \& Planning, Cambridge, MA 02139 USA

+ [4] Univ Waterloo, Dept Geog \& Environm Management, Waterloo, ON, Canada

+ [5] Univ Teknol Malaysia, AHIBS, Kuala Lumpur, Malaysia

E-mail Addresses: amin.cantt@gmail.com

Funding
\begin{tabular}{|l|l|}
\hline Funding Agency & Grant Number \\
\hline Ministry of Education of Malaysia & \\
\hline UNITEN BOLD & $10289176 / \mathrm{B} / 9 / 2017 / 18$ \\
\hline UTM & \\
\hline UNITEN & \\
\hline & $18 \mathrm{H} 14$ \\
\hline
\end{tabular}

View funding text

Publisher

ELSEVIER, RADARWEG 29, 1043 NX AMSTERDAM, NETHERLANDS

\section{Categories / Classification}

Research Areas: Environmental Sciences \& Ecology; Meteorology \& Atmospheric Sciences

Web of Science Categories: Environmental Sciences; Meteorology \& Atmospheric Sciences

\section{Citation Network}

In Web of Science Core Collection

1

Times Cited

Create Citation Alert

All Times Cited Counts

1 in All Databases

See more counts

\section{0}

Cited References

View Related Records

Most recently cited by:

Dezso, Zsuzsanna; Pongracz, Rita; Bartholy, Judit.

Analysis of Surface Temperature Measurements over Complex Urban Sites. GEOGRAPHICA PANNONICA (2019)

View All

\section{Use in Web of Science}

Web of Science Usage Count

\section{$13 \quad 13$}

Last 180 Days $\quad$ Since 2013

Learn more

This record is from

Web of Science Core Collection - Science Citation Index Expanded - Social Sciences Citation Index

Suggest a correction

If you would like to improve the quality of the data in this record, please suggest a correction.

See more data fields 
Cited References: 90

1. Climate change issues and Malaysian initiatives

By: Al-Amin, A.Q.; Jaafar, A.H.; Azam, M.N.; et al.

Climate Change Governance Pages: 141-151 Published: 2013

Publisher: Springer, Berlin, Heidelberg

[Show additional data]

2. Prioritizing climate change mitigation: An assessment using Malaysia to reduce carbon emissions in future

Times Cited: 21

By: Al-Amin, Abul Quasem; Rasiah, Rajah; Chenayah, Santha

ENVIRONMENTAL SCIENCE \& POLICY Volume: 50 Pages: 24-33 Published: JUN 2015

3. Food Security Challenge of Climate Change: An Analysis for Policy Selection

Times Cited: 5

By: Al-Amin, Abul Quasem; Ahmed, Ferdous

FUTURES Volume: 83 Special Issue: SI Pages: 50-63 Published: OCT 2016

4. An overview of prospects and challenges in the field of climate change in Malaysia

Times Cited: 13

By: Al-Amin, Abul Quasem; Filho, Walter Leal

INTERNATIONAL JOURNAL OF GLOBAL WARMING Volume: 3 Issue: 4 Pages: 390-402 Published: 2011

5. Agricultural vulnerability and adaptation to climatic changes in Malaysia: review on paddy sector.

Times Cited: 8

By: Alam, M. M.; Chamhuri Siwar; Abdul Hamid Jaafar; et al.

Current World Environment Volume: 8 Issue: 1 Pages: 1-12 Published: 2013

6. Multi-level governance

Times Cited: 1

By: Bache, I.; Bartle, I.; Flinders, M.

HDB THEORIES GOVERNA Published: 2016

Publisher: Edward Elgar Publishing

7. Impact of urbanization growth on Malaysia $\mathrm{CO} 2$ emissions: Evidence from the dynamic relationship

Times Cited: 5

By: Bekhet, Hussain Ali; Othman, Nor Salwati

JOURNAL OF CLEANER PRODUCTION Volume: 154 Pages: 374-388 Published: JUN 152017

8. Title: [not available]

Times Cited: 1

By: Bernama.

Melaka Going Greener through Industry Driven Smart Communities Program: Pthm-Might Collaborates to Launch Energy Efficiency Energy Performance Contracting (Epc) Projects for Private Sector in Melaka Published: 2014

9. Looking Back and Thinking Ahead: A Decade of Cities and Climate Change Research

By: Betsill, Michele; Bulkeley, Harriet

LOCAL ENVIRONMENT Volume: 12 Issue: 5 Special Issue: SI Pages: 447-456 Published: 2007

10. Beyond the intergovernmental regime: recent trends in global carbon governance

Times Cited: 41

By: Biermann, Frank

CURRENT OPINION IN ENVIRONMENTAL SUSTAINABILITY Volume: 2 Issue: 4 Pages: 284-288 Published: OCT 2010

11. Title: [not available]

Times Cited: 6

By: Biesbroek, G.R.

Challenging Barriers in the Governance of Climate Change Adaptation Published: 2014

Publisher: Wageningen University, Netherlands

12. Public Bureaucracy and Climate Change Adaptation

Times Cited: 10

By: Biesbroek, Robbert; Peters, B. Guy; Tosun, Jale

REVIEW OF POLICY RESEARCH Volume: 35 Issue: 6 Special Issue: SI Pages: 776-791 Published: NOV 2018

13. What cities do best: Piecing together an efficient global climate governance

Times Cited: 1

By: Broekhoff, D.; Erickson, P.; Lee, C.M.

Working Paper Published: 2015

Publisher: Stockholm Environment Institute, Stockholm

14. Climate change, migration and violent conflict: Vulnerabilities, pathways and adaptation strategies

Migr. Dev Volume: 5 Pages: 190-210 Published: 2016

CrossRef 
The nature of policy change and implementation: A review of different theoretical approaches Published: 2013

Publisher: OECD

URL: https://www.oecd.org/edu/ceri/The $\% 20$ Nature $\% 20$ of $\% 20$ Policy $\% 20$ Change $\% 20$ and $\% 2$ Implementation.pdf

18. Title: [not available]

Group Author(s): City of Kansas City

Climate Protection Plan Published: 2008

Publisher: City of Kansas City, Missouri, USA

19. Can low-carbon urban development be pro-poor? The case of Kolkata, India

Times Cited: 4

By: Colenbrander, Sarah; Gouldson, Andy; Roy, Joyashree; et al.

ENVIRONMENT AND URBANIZATION Volume: 29 Issue: 1 Pages: 139-158 Published: APR 2017

20. Justice-relevant conditions to participation in biodiversity governance: An ex-ante approach to environmental justice

Times Cited: 1

By: Coolsaet, B.

ROYAL GEOGR SOCANN Published: 2014

21. Title: [not available]

Times Cited: 30

By: Corfee-Morlot, J.; Kamal-Chaoui, L.; Donovan, M. G.; et al.

CITIES CLIMATE CHANG Volume: 14 Published: 2009

URL: http://HTTP://WWW.OECD.ORG/GOV/REGIONALDEVELOPMENT/44232263.PDF

[Show additional data]

22. Cities and climate change: Harnessing the potential for local action (chapter 2)

Times Cited: 1

By: Corfee-Morlot, J.; Cochran, I.; Pierre-Jonathan, T.

COMP CIT CLIM CHANG Published: 2008

23. Sustainable-smart-resilient-low carbon-eco-knowledge cities; making sense of a multitude of concepts promoting sustainable urbanization

Times Cited: 196 By: de Jong, Martin; Joss, Simon; Schraven, Daan; et al.

JOURNAL OF CLEANER PRODUCTION Volume: 109 Special Issue: SI Pages: 25-38 Published: DEC 162015

24. ADAPTATION, VARIATION, AND CULTURAL-GEOGRAPHY

Times Cited: 87

BY: DENEVAN, WM

PROFESSIONAL GEOGRAPHER Volume: 35 Issue: 4 Pages: 399-407 Published: 1983

25. The struggle to govern the commons

Times Cited: 1,812

By: Dietz, T; Ostrom, E; Stern, PC

SCIENCE Volume: 302 Issue: 5652 Pages: 1907-1912 Published: DEC 122003

26. Title: [not available]

Times Cited: 7

By: Edenhofer, 0

Climate change 2014: mitigation of climate change Volume: 3 Published: 2015

Publisher: Cambridge University Press

27. A rights-based perspective on adaptive capacity

Times Cited: 32

By: Ensor, J. E.; Park, S. E.; Hoddy, E. T.; et al.

GLOBAL ENVIRONMENTAL CHANGE-HUMAN AND POLICY DIMENSIONS Volume: 31 Pages: $38-49$ Published: MAR 2015

28. Title: [not available]

Times Cited: 12

By: Erickson, P.; Tempest, $\mathrm{K}$.

Advancing climate ambition: cities as partners in global climate action. Produced by SEl in Support of the UN Secretary-General's Special Envoy for Cities and Climate Change and C40 Published: 2014

29. Technologies, policies and measures for GHG abatement at the urban scale 
Inclusive Green Growth: The Pathway to Sustainable Development Published: 2012

Publisher: World Bank Publications

Showing $\mathbf{3 0}$ of $90 \quad$ View All in Cited References page

\section{Clarivate}

(c) 2020 Clarivate Copyright notice Terms of use Privacy statement

Cookie policy 